\title{
The Iranian quagmire: How to move forward
}

\section{Mustafa Kibaroglu}

To cite this article: Mustafa Kibaroglu (2010) The Iranian quagmire: How to move forward, Bulletin of the Atomic Scientists, 66:6, 102-108, DOI: 10.1177/0096340210387504

To link to this article: http://dx.doi.org/10.1177/0096340210387504

$$
\text { 曲 Published online: } 27 \text { Nov } 2015 .
$$

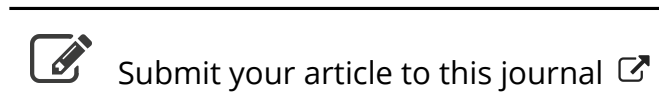

\section{Џ Article views: 15}

Q View related articles ¿

4 Citing articles: 5 View citing articles 


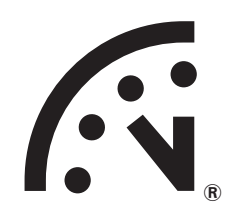

Global forum

\title{
The Iranian quagmire: How to move forward.
}

\section{Position: Resuscitate the nuclear swap deal}

\author{
Mustafa Kibaroglu
}

\begin{abstract}
As the writers in this symposium illustrate, dealing with Iran's nuclear program is one of the most important foreign policy issues of the day. Years of stalled talks, diplomatic dead-ends, and sanctions have made it difficult to see exactly where progress has been made and what efforts are worth pursuing. In this Global Forum, leading foreign policy experts weigh in from around the world on the options for how to move forward with Iran-from diplomacy to fuel swaps to military strikes. Whatever their proposed solutions, the writers express one common theme: We ignore Iran at our own peril. From the US, Thomas R. Pickering (20I0), Lawrence J. Korb (2010), and Bennett Ramberg (2010); from Turkey, Mustafa Kibaroglu; from Iran, Kayhan Barzegar (2010); and from Israel, Emily B. Landau (2010). Over the months of November and December, this forum will continue at www.thebulletin.org.
\end{abstract}

\section{Keywords}

Brazil, Bushehr, diplomacy, fuel, IAEA, Iran, nuclear power, Turkey

ran's nuclear program entered a new phase of ambiguity as to the ambitions of its clerical leaders with the start of operations in the Bushehr nuclear power plant in August 2010-almost a decade later than scheduled, according to the January 1995 contract signed in Tehran between Russia and Iran. The implications of Iran's nuclear program, the challenges and risks it could pose to international security and stability, continue to be among the most hotly debated topics in political, military, and academic circles around the world. While the consequences of Iran's eventual weaponization of its nuclear capabilities and the implications in terms of the security of the countries in the Middle East constitute one side of this debate, the other side of the debate focuses on the consequences of the steps that may be taken to stop such a contingency and whether a military operation against Iran's nuclear facilities to achieve such a goal would be a remedy to the problem, or whether it would aggravate the situation even further.

Each side of the debate has a powerful case, accompanied by convincing arguments and substantiating facts and 
figures - on the one hand, assertions that carefully planned, surgical military strikes at selected sites would bring down not only the technological capabilities of Iran but also the morale of the Iranian society and its clerical leaders, and thus considerably retard, if not definitely put a halt to, Iran's ambitions to develop nuclear weapons; and, on the other hand, suggestions of non-military measures, such as diplomacy, to ensure Iran observes the norms of the international community.

That said, the question is not which argument makes more sense but, rather, whether any of these arguments would really serve to break the apparent deadlock, where stakes are high for all parties concerned. A military operation against Iran's nuclear facilities-no matter how sophisticated or militarily successful-will not thwart Iran's nuclear ambitions once and for all; nor will shallow and incomplete diplomatic initiatives bring Iran to terms with its legally binding obligations and responsibilities toward the international community as stated in Article III of the Nuclear Non-Proliferation Treaty (NPT). Many suggestions in the debate on Iran would not halt the military dimensions of Iran's nuclear program. So, then, what course of action should the international community adopt and implement?

\section{Military strikes or shallow diplomatic initiatives won't solve the problem}

Neither the military option nor shallow diplomacy will help Iran meet the international community's expectations that it act responsibly with respect to its obligations and rights stemming from
Article IV of the NPT. Shallow diplomacy here denotes ad hoc diplomatic initiatives not supported by comprehensive and long-term action plans, underwritten by powerful governmental assurances of the states involved, and also those conditional upon Iran's taking some steps, beforehand, in the direction prescribed by those states.

\section{Drawbacks of military option}

Regarding the military option, the most important questions are not how many nuclear facilities does Iran have and where are they located, or which are dummy sites built with the sole purpose of fooling the enemy. The question is whether Iran's determination to become a nuclear power will be weakened as a result of a successful military operation.

Before considering anything else, one must bear in mind that the Iranian population is highly committed to going ahead with all the aspects of the country's nuclear program, and this is possibly the single most important issue uniting the diverse groups within Iranian society, regardless of their deep divergence of opinion vis-à-vis other political, economic, and even cultural issues. ${ }^{\text {I }}$ There are basically two reasons why Iranian society lends its utmost support to the nuclear program. One is the belief that nuclear weapon capability will answer the security needs of the country in the face of the perceived threats, especially from the United States and Israel. Second, most Iranians-from the average person on the street to the country's intellectuals and clerical leaders-believe it is Iran's solemn duty to elevate the country to the league of the leading nations in the 
world, one characteristic of which is the possession of nuclear power; moreover, they believe they must achieve this goal to be true to the "glorious past" of their centuries-old Persian civilization (Del Giudice, 2008). ${ }^{2}$ The following views of an Iranian scholar perfectly summarize the atmosphere in the Iranian public domain:

\begin{abstract}
Three pillars of Iranian strategic thinking are important to understand. The first is Iranians' sense of victimization [because of the attitude of the West after the Islamic Revolution, especially during the war with Iraq]. Second is Iranians' quest for recognition. Third is continuity with the pre-Revolutionary period. Iran is a proud country, a big country, and a leading country. This must be recognized. The sense of Iran as a leading country is something to which the leadership pays heavy attention. The psychological deficit within the Iranian leadership could be fulfilled by developing nuclear weapons capability. (Kibaroglu, 2006: 219$)^{3}$
\end{abstract}

Against this backdrop, it seems unlikely that a military operation would succeed-militarily or politically-especially given the lack of precise intelligence about the location of every Iranian nuclear facility of potential significance to the country's nuclear aspirations. It must also be remembered that, following the inspections by the International Atomic Energy Agency (IAEA) at the Qom enrichment facility, which was unearthed while under construction, the officials admitted that the agency was not in a position to confirm there were no other secret nuclear facilities in Iran. ${ }^{4}$ Hence, the military option is actually not an option, because an attack, even if devastating, could make Iran even more powerful and harden the resolve of the Iranian leadership to acquire nuclear weapon capability, given that the nuclear knowledge and technical know-how they have accumulated thus far cannot be destroyed.

\section{Shortcomings of shallow diplomatic initiatives}

If the military option is not an option, then who will stop Iran from advancing its nuclear capabilities and how? This is a very valid question. And the answer is to pursue effective diplomacy, rather than shallow diplomatic initiatives that are seemingly designed to augment some countries' or individuals' profiles in the international arena (or so they seem to believe).

Iran has a very long history of ruling large territories across the Eurasian landscape, thereby building strong diplomatic skills and acquiring vast knowledge about world politics. One should not, therefore, confuse the current Iranian administration with what Western policy analysts perceive as a "typical" Middle Eastern state structure-that is, one heavily dependent on a male leader and his entourage of close family members, who, in times of crisis, may not necessarily display the resolve to serve his country. Iran has a long and solid tradition of statehood, and regardless of the regime's characteristics, Iranian diplomats, even though they may not be masterminds of contemporary diplomacy, are known for making negotiations difficult for their counterparts. They cannot be easily fooled with superficial proposals that may lead nowhere. Iranians want to be taken seriously and offered comprehensive proposals with long-term implications for the security and prosperity of their country. 
Notwithstanding the expectations of the Iranian leadership to be taken more seriously, especially by Western countries, most diplomatic initiatives so far have been either non-starters-setting out conditions before any incremental step could be taken in favor of Iran-or have not been pursued long enough, with sufficient patience and good faith, on the grounds that Iran would cheat anyway. The following statement summarizes the prevailing view in Western political circles:

\begin{abstract}
The EU-3 argue that Iran cannot be trusted to control the whole nuclear fuel-cycle-even under international supervision. They fear that technology developed under a pilot scheme could be used in a secret military project. They argue that Iran's history of pursuing a covert programme for I8 years means that it cannot be given the benefit of the doubt. Therefore, the only way Iran could provide a satisfactory guarantee would be to announce a permanent end to all uranium enrichment activities, to be verified by international inspections. (Leonard, 2005: 6)
\end{abstract}

This attitude, pervasive in the West, does indeed play into the hands of the Iranian administration. It gives Iran the opportunity to exploit the situation: Under the pretext of being treated as an "outlaw" state, Iran feels justified in further distancing itself from the outer world's scrutiny.

\section{What can be done to thwart Iran's nuclear ambitions?}

What needs to be done to thwart Iran's nuclear ambitions? This is truly a “\$64,00o question," and not at all easy to answer. It is easier to postulate arguments about what is not feasible or what is wrong, and why. However, it is difficult-especially after having explored numerous options for thwarting Iran's nuclear ambitions-to offer policy suggestions that both make sense and are feasible.

That said, there are many reasons a multilateral initiative must be given a genuine opportunity to help achieve a lasting solution to the problem. Though unexpectedly aborted, this initiative-namely the "nuclear swap deal" agreed by Turkey, Brazil, and Iran in Tehran on May I7, 2010-must be resuscitated and then truly exploited by the international community with all possible extensions attached to it, such as not going ahead with enrichment activities until the end of the swap period, as a confidence-building measure.

The nuclear swap deal was literally the one and only document Iran ever signed over the many years since the debate on its nuclear program began to dominate international political discourse. Iranians flatly rejected allegations of pursuing a hidden agenda to create a nuclear weapon and opposed any proposals that required them to stop or suspend any of the sensitive activities in their nuclear program, such as uranium enrichment, citing its inalienable right to benefit from peaceful applications of nuclear energy. There was a short period between late 2003 and early 2005, during which Iran cooperated with both the IAEA and the EU-3 - the United Kingdom, France, and Germany-which offered Iran several political and economic incentives in return for allowing the IAEA inspectors to visit a number of military sites such as the Parchin Military Base near Tehran, and to suspend the installation of centrifuges to the Natanz enrichment facility. Yet, neither the demands nor the 
incentives were officially documented or made mandatory for Iran-"promises" were to constitute the basis of cooperation. Similarly, Iran's primary and only (other than the alleged "A. Q. Khan network") nuclear technology supplier, namely Russia, which built the Bushehr nuclear power plant, also worked hard in the second half of 2009 to convince Iran to sign an agreement that would have resulted in the removal of a significant amount of low-enriched uranium (LEU) produced in Natanz. These efforts failed after "long and tiring deliberations." 5

However, in 20I0, Turkey, a neighbor and, indeed, historic rival of Iran, worked hard and finally succeeded, with the support of Brazil, in bringing Iran to the negotiating table and in securing the signing of the Joint Declaration of the Ministers of Foreign Affairs of Turkey, Iran, and Brazil in Tehran in May. The signing ceremony was given further moral support by the participation of Turkish Prime Minister R. Tayyip Erdogan, Iranian President Mahmoud Ahmadinejad, and Brazilian President Lula da Silva.

With the Joint Declaration, Iran agreed, among other things, to store some $1,200 \mathrm{~kg}$ of its LEU in Turkey for I2 months; at the end of this time, the Vienna Group, composed of the United States, France, Russia, and the IAEA, would give Iran $120 \mathrm{~kg}$ of uranium enriched to 20 percent to be used in the Tehran Research Reactor to create medical isotopes. The so-called "swap deal" was not, of course, the end of the story, solving all the problems between Iran and the West. However, in paragraph three of the Joint Declaration, the three signatories state that they "believe that the nuclear fuel exchange is instrumental in initiating cooperation in different areas, especially with regard to peaceful nuclear cooperation including nuclear power plant and research reactors construction" (Turkish Ministry of Foreign Affairs, 20I0). In the same vein, it was also declared that "based on this point the nuclear fuel exchange is a starting point to begin cooperation and a positive constructive move forward among nations" (Turkish Ministry of Foreign Affairs, 20IO).

However, this unique opportunity was killed in action by the countries, such as the United States, that have long accused Iran of not cooperating enough or not coming to the negotiation table in good faith; but also by the European Union, Russia, and China who lent no support to the genuine (and fruitful) efforts of Turkey and Brazil. No one can explain why the United States abruptly changed its position on the deal, with Secretary of State Hillary Clinton calling it "a transparent ploy to avoid Security Council action" (CBS News, 20I0) only 27 days after President Barack Obama had written to Brazil's da Silva (on April 2o) suggesting they try to get Iran to agree to terms almost identical to those in the May I7 swap deal. Apparently, the deal fell victim to the political rift between the US president's office and the State Department.

Had Turkey's (and Brazil's) efforts been endorsed by the leading powers of the world, relations with Iran might have been put on a healthy track, whereby the Iranian clerical leaders could agree to further steps that would eventually lead to the normalization of relations between Iran with the Western world. Turkey used its growing "soft power" and its genuine desire to solve 
this problem on Iran. There are tangible signs that Turkey's efforts, in particular, could result in further agreements with Iran with respect to its nuclear program.

One may ask what's at stake for Turkey in this puzzle. There are three issues that must be considered. First of all, in October 2008, Turkey was elected to the United Nations Security Council as a Non-Permanent Member for 2009 and 20Io. Hence, it is Turkey's duty to take part in activities that aim to preserve peace and security in the world, and the question of Iran's nuclear ambitions is obviously an issue of international security. So, Turkey could not stay out of it. Second, Turkey does not want either the United States or Israel to justify a military operation on the pretext that Iran is escaping any diplomatic solution. Third, Turkey does not want Iran to justify the further advance of its nuclear capabilities (by, for instance, enriching its LEU up to 20 percent) on the pretext of not getting enough support from the rest of the world. It must be clearly understood that Turkey does not want Iran to develop nuclear weapons. Nor does it want to see other countries in the region with nuclear weapons capability. Why? Because "Turkey is a country that will be most negatively affected by Iran's nuclear-weapons capability, if and when it is developed" (Kibaroglu and Caglar, 2008: 59).

Hence, the nuclear swap deal must be taken out of the fridge and put back on the negotiating table with the support of the international community. Only by making Iran sign legally binding documents which address the country's contemporary security concerns and economic needs, will Iranian nuclear ambitions be thwarted. No one can say this is a sure way to succeed, but it is much more likely to produce tangible results than are other options, and, therefore, absolutely worth another try, before it's too late.

\section{Notes}

I. Iranian intellectuals, scholars, and government officials, in private conversations, generally express the view that Iran should advance its nuclear program, at least, to the level of Japan and Germany in terms of scientific and technological capabilities. Because, they believe, only then may they both entertain the peaceful applications of nuclear energy on a large scale and also eventually weaponize their peaceful nuclear capability, if need be, in the case that there is a serious perceived threat.

2. The recorded history of Iran spans some 2,500 years that makes most Iranians proud. Iranians claim that "at one time the area of the country was triple what it is now, and it was a stable superpower for more than a thousand years," and that they "have a nostalgia to be a superpower again." For research on Iran's "glorious past", see Del Giudice (2008).

3. Views expressed by Dr. Gholamali Chegnizadeh, from the Faculty of Law and Political Science at the University of Allame Tabatabaee in Tehran, during the author's research in Iran in 2005, and quoted in Kibaroglu (2006).

4. Authorities in the International Atomic Energy Agency (IAEA) complain about the level of cooperation between the agency and Iran on a number of issues including the "possible military dimensions" of some of the activities in Iranian nuclear facilities. The following excerpt from the IAEA's board report may be an indicator of the lack of satisfaction of agency officials with Iran's performance. Section G, paragraph 35 of the report reads as follows: "Based on an overall analysis undertaken by the Agency of all the information available to it, the Agency remains concerned about the possible existence in Iran of past or current undisclosed nuclear related activities, involving 
military related organizations, including activities related to the development of a nuclear payload for a missile. There are indications that certain of these activities may have continued beyond 2004" (IAEA, 20I0: 8).

5. Conversations with Russian colleagues (not to be disclosed here) involved in these deliberations throughout the second half of 2009 .

\section{References}

Barzegar K (20I0) The Iranian quagmire: How to move forward. Position: Tit-for-tat diplomacy. Bulletin of the Atomic Scientists 66(6): I09-II4.

CBS News (20I0) Clinton: Iran nuclear fuel swap offer is 'ploy.' May 25. Available at: http:// www.cbsnews.com/stories/20I0/05/25/world/ main6517434.shtml.

Del Giudice M (2008) Persia: Ancient soul of Iran: A glorious past inspires a conflicted nation. National Geographic, August. Available at: http://ngm.nationalgeographic.com/2008/o8/ iran-archaeology/del-giudice-text/I.

International Atomic Energy Agency (IAEA) (20I0) Implementation of the NPT safeguards agreement and relevant provisions of Security Council resolutions 1737 (2006), I747 (2007), I803 (2008) and I835 (2008) in the Islamic Republic of Iran. Report by the director general, May 3I. Available at: http://www.isis-online.org/ uploads/isis-reports/documents/IAEA_Report_ Iran_3IMay2oio.pdf.

Kibaroglu M (2006) Good for the Shah, banned for the Mullahs: The West and Iran's quest for nuclear power. Middle East Journal 6o(2): 207-232.
Kibaroglu M and Caglar B (2008) Implications of a nuclear Iran for Turkey. Middle East Policy I5(4): $59-80$.

Korb LJ (20I0) The Iranian quagmire: How to move forward. Position: Containment and deterrence. Bulletin of the Atomic Scientists 66(6): 95-IOI.

Landau EB (20I0) The Iranian quagmire: How to move forward. America, not Israel, at the helm. Bulletin of the Atomic Scientists 66(6): II5-I20.

Leonard M (2005) Can EU diplomacy stop Iran's nuclear program? Working paper, Center for European Reform, November. Available at: http://www.cer.org.uk/pdf/wp645_dip_iran_ nuclear.pdf.

Pickering TR (20I0) The Iranian quagmire: How to move forward. Position: Confident diplomacy. Bulletin of the Atomic Scientists 66(6): 88-94.

Ramberg B (20I0) The Iranian quagmire: How to move forward. Position: The military option. Bulletin of the Atomic Scientists 66(6): I2I-I29.

Turkish Ministry of Foreign Affairs (20I0) Joint Declaration of the Ministers of Foreign Affairs of Turkey, Iran and Brazil. May I7. Available at: http://www.mfa.gov.tr/I7_05_20IO-joint-declaration-of-the-ministers-of-foreign-affairs-ofturkey_-iran-and-brazil_.en.mfa.

\section{Author biography}

Mustafa Kibaroglu teaches courses on arms control and disarmament in the Department of International Relations at Bilkent University in Ankara, Turkey. He is also the Academic Advisor of NATO Centre of Excellence Defence against Terrorism in Ankara, Turkey. Additional information and writings can be found at: www.mustafakibaroglu.com. 